Hydrol. Earth Syst. Sci., 17, 3235-3244, 2013

www.hydrol-earth-syst-sci.net/17/3235/2013/

doi:10.5194/hess-17-3235-2013

(c) Author(s) 2013. CC Attribution 3.0 License.

\title{
Towards understanding the dynamic behaviour of floodplains as human-water systems
}

\author{
G. Di Baldassarre ${ }^{1, *}$, M. Kooy ${ }^{1}$, J. S. Kemerink ${ }^{1}$, and L. Brandimarte ${ }^{1}$ \\ ${ }^{1}$ UNESCO-IHE Institute for Water Education, Delft, the Netherlands \\ *Invited contribution by G. Di Baldassarre, recipient of the EGU Division Outstanding Young Scientists Award 2012.
}

Correspondence to: G. Di Baldassarre (g.dibaldassarre@unesco-ihe.org)

Received: 10 March 2013 - Published in Hydrol. Earth Syst. Sci. Discuss.: 25 March 2013

Revised: 24 June 2013 - Accepted: 12 July 2013 - Published: 15 August 2013

\begin{abstract}
This paper offers a conceptual approach to explore the complex dynamics of floodplains as fully coupled human-water systems. A number of hydrologists have recently investigated the impact of human activities (such as flood control measures, land-use changes, and settlement patterns) on the frequency and severity of floods. Meanwhile, social scientists have shown how interactions between society and waters in deltas and floodplain areas, including the frequency and severity of floods, have an impact on the ways in which social relations unfold (in terms of governance processes, policies, and institutions) and societies are organised (spatially, politically, and socially). However, we argue that the interactions and associated feedback mechanisms between hydrological and social processes remain largely unexplored and poorly understood. Thus, there is a need to better understand how the institutions and governance processes interact with hydrological processes in deltas and floodplains to influence the frequency and severity of floods, while (in turn) hydrological processes co-constitute the social realm and make a difference for how social relations unfold to shape governance processes and institutions. Our research goal, therefore, is not in identifying one or the other side of the cycle (hydrological or social), but in explaining the relationship between them: how, when, where, and why they interact, and to what result for both social relations and hydrological processes? We argue that long time series of hydrological and social data, along with remote sensing data, can be used to observe floodplain dynamics from unconventional approaches, and understand the complex interactions between water and human systems taking place in floodplain areas, across scales and levels of human impacts, and within different hydro-climatic conditions, socio-cultural settings, and modes of governance.
\end{abstract}

\section{Introduction}

Since the earliest recorded civilisations, such as those in Mesopotamia and Egypt that developed in the fertile riparian areas of the Tigris and Euphrates and Nile rivers, humans have settled in floodplain areas, as the ecological conditions and geographical location offered favourable conditions for cultural organisation, agricultural development, trade, and economic growth (Di Baldassarre et al., 2010). With the evolution of food production, water and communication technologies, infrastructure systems, and shifts in economic systems (pre-modern to capitalist), many societies are no longer reliant on direct proximity to the floodplain for favourable development conditions. Nevertheless, floodplain areas today are home to some of the largest urban settlements (McGranahan et al., 2007); nine of the ten largest urban agglomerates in the world (United Nations, 2012) are located in deltas or floodplain areas, with most of them in the global south. While human settlements and subsequent methods of production and land use have changed in composition and form over time, they have undoubtedly grown in sheer size and ecological impact. As a result, flooding nowadays affects more than 100 million people per year, and it is the most damaging natural hazard as it causes about half of all deaths from weather-related disasters (Ohl and Tapsell, 2000; Opperman et al., 2009). Flood risk is dramatically increasing in many parts of the world because of increasing population growth in floodplains, leading to considerable changes in land use and/or the impact of climate change (Milly et al., 2002; Di Baldassarre et al., 2010). Moreover, this risk is not equally distributed throughout society, as some population groups have more resources than others to prevent, mitigate, or recover from flood events (Masozera et al., 2007). 
The global increase in flood risk, and related complex of socio-political, economic, and ecological problems is at the forefront of much current research (Apel et al., 2009; Di Baldassarre et al., 2010; Lane et al., 2011; Landstrom et al., 2011; Di Baldassarre and Uhlenbrook, 2012; Harvey et al., 2012; Pappenberger et al., 2012; Winsemius et al., 2013; www.kulturisk.eu). However, as we argue in this paper, a sufficient understanding of the dynamics of flood risk is still lacking, preventing the formulation of sustainable and equitable floodplain management strategies. We argue that addressing the challenges of floodplains (minimising the impact of flood events, while maintaining ecosystem services and supporting continued ecologically sustainable and socially inclusive human life) urgently requires the development of new types of knowledge, based on the insights from both natural and social scientists, using theories of socialnature interactions in a transdisciplinary research agenda. Transdisciplinary approaches (see also Jahn et al., 2012) focus on integrating knowledge produced within different scientific disciplines as well as knowledge produced outside of academia (i.e. lay knowledge).

The following sections of the article proceed to discuss recent theoretical insights from hydrological sciences that forward a transdisciplinary analysis of floodplain systems as co-produced by social and natural processes (Sect. 2), and then discuss theoretical insights from social sciences that forward a transdisciplinary analysis of floodplain systems as co-produced by social and natural processes (Sect. 3). We follow this by illustrating why, particularly in floodplains, the dynamic interrelations between social realms (i.e. intersect of political, economical, cultural domains) and nature are apparent (Sect. 4), as well as the current limitations in understanding floodplain systems (Sect. 5). We then set out our argument, based on the above, as to why floodplain research and flood risk science require a new transdisciplinary approach (Sect. 6), and we conclude by exploring the way forward to develop the necessary research methodologies needed to understand the combined social and natural composition of floodplains across time and space (Sect. 7).

\section{Theorising floodplain systems from the perspective of hydrological sciences}

In the past decades, several scientific studies have been carried out by hydrologists to understand flood processes, and many numerical models predicting floodplain inundation and river hydraulics have been developed (Bates and De Roo, 2000; Nardi et al., 2006; Hunter et al., 2007; Bates, 2012). Some of these models have proved capable of making reliable predictions of the areas that can potentially be inundated in case of flooding (Horritt et al., 2007; Di Baldassarre et al., 2009). Thus, floodplain models are nowadays widely used in flood risk management as floodplain mapping, in particular, can support land-use and urban planning, raise the awareness of people living in flood prone areas, and improve the resilience of human settlements in floodplains (Di Baldassarre and Uhlenbrook, 2012). However, all these floodplain models focus on the hydrological processes and do not explicitly simulate the interactions with human activities.

In recent years, many physical scientists, geomorphologists, and hydrologists have pointed to what they identify as the increased impact of societies on hydrological systems in most regions of the world (Sanderson et al., 2002; Liu et al., 2007; Werner and MacNamara, 2007; Kareiva et al., 2007; Di Baldassarre et al., 2010; Wagener et al., 2010). Savenije et al. (2013), for instance, identified four main types of human impacts on catchment hydrology: (i) direct diversion of water flows (e.g. water supplies to cities, industries and agriculture, (ii) stream network transformation (e.g. construction of dams and reservoirs), (iii) changing river basin characteristics (e.g. deforestation, urbanisation, drainage of wet-lands and agricultural practices), and (iv) alteration of the regional or global climate (e.g. greenhouse gas emissions and land cover changes).

In this context, Sivapalan et al. (2012) argued that a fundamental science underpinning integrating water resources management is still missing and provided future directions for the new discipline of socio-hydrology. In particular, they emphasised the need to go beyond the study of hydrological processes in pristine areas and investigate how societies live and interact with a changing biophysical environment. Sociohydrology will also have a crucial role in "Pantha Rei", the upcoming IAHS (International Association of Hydrological Sciences) Scientific Decade (Montanari et al., 2013).

Other natural scientists have approached the validity of floodplain models from different yet related directions, illustrating the ways in which knowledge regarding flooding is co-produced through science and politics, and calling for the production of localised datasets to run models predicting spatial inundation. In particular, Lane et al. (2011) call attention to the ways in which different types of social interaction with the biophysical environment, through forms of river maintenance, influence water levels and flood risk, and the need to include these variables within model functions (Lane et al., 2011; Landstrom et al., 2011). This latter point supports our argument regarding the need to consider the ways in which societies interact with water as constitutive of hydrological processes, and the need to include social-nature interactions as integral, not external, to hydrological science.

\section{Theorising floodplain systems from the perspective of social sciences}

In a parallel, but not yet connected, avenue of research, social scientists have for many years called attention to the ever present interaction between societies and natures. $\mathrm{Hu}-$ man geographers have shown that there has never been a prior "natural" environment (Braun, 2002), and argue notions 
of society or nature as a domain separate from the other are false (Latour, 1991; Swyngedouw, 1999; Castree and Braun, 2001; Ostrom, 2009). Supporting this claim toward a combined social-nature, social scientists have sought to illustrate the ways in which people, technologies, organisms and geophysical processes are woven together through water (Rademacher, 2011; Carse, 2012; Pritchard, 2011; Barnes, 2012).

Environmental historians have demonstrated how aquatic features such as rivers are not givens but, rather, are shaped through the intertwining of human and nonhuman natures (Cioc, 2002; White, 1996; Worster, 1992). Similarly, geographers and sociologists have illustrated how hydrological processes and geo-morphological properties have been constitutive of social relations and organisation (Carroll 2012; Braun, 2000; Mosse, 2003). Sociologists, anthropologists and geographers have all shown how the hydrological properties of water are not fixed, but changed through interactions with society, both discursively for instance with the standardisation of water as $\mathrm{H}_{2} \mathrm{O}$ as a product of economic modernisation (Hamlin, 1990), and materially as the quality and quantity are changed through water abstraction, pollution and treatment processes (Lucklin, 1987; Tarr, 1996; Gandy, 2002). Other research has destabilised the presumed fixity of the hydrological cycle (Linton, 2010) showing how it was socially constructed in a particular historical and geographical setting.

Complex systems theory has also examined interactions between nature and society. The theory was first used by ecologists to explain (unexpected) dramatic shifts in ecosystems as a result of human impacts (Berkes and Folke, 1998; Gunderson et al., 1995; Gunderson and Holling, 2002; Scheffer et al., 2001). Interactions and reactions between ecological and human agents were identified as creating causal loops, producing non-linear, emergent, self-organising, and adaptive social-ecological systems (SES). Since its origins in ecological sciences, the SES approach has been applied in other social science disciplines to develop normative concepts for natural resources management (Armitage et al., 2007; Ostrom, 2009). In comparison to other social science frameworks used to examine social-nature interactions (described in the previous paragraph), SES theory pays very little attention to ways in which relations of (political, economic and social) power shape interactions between social and natural agents.

More recently, attention has been paid in the field of science and technology studies to how social realms not only produce the symbolic, social, and hydrological properties of water, but also how social realms are built, at least partially, in and through engagements with water (Barnes and Alatout, 2012; Budds, 2009). Responding to criticisms of social constructivism, social-nature studies are becoming more balanced by attention to how hydrological processes and material properties in turn make a difference to how social re- lations unfold and how societies become organised (Bakker, 2012).

Hence, we posit that social relations (embedded in political economies, institutional configurations, cultural organisations) are seen as always having been constitutive of how we perceive, understand, order, interact and ultimately re-order physical environments, while the hydrological environment also 'matters' and must be internalised in understanding societies.

\section{Floods and societies: relationships between the social and the "natural"}

This paper argues that a socio-hydrological approach is particularly needed for the study of floodplain dynamics as most floodplains have been impacted by the presence of human settlements since the first recorded civilisations. Indeed, populated floodplains are ideal laboratories for the study of socio-hydrological processes as the interactions between human and water systems are apparent and have dramatic impacts. In floodplains, human settlements, flood control measures and the hydrology of floods have gradually co-evolved at similar temporal (years to decades) and spatial (floodplain) scales, while they are also abruptly affected by the sudden and localised occurrence of flood events. As mentioned, many societies in floodplains were significantly shaped by the occurrence of floods, while the frequency of floods was being significantly shaped by societies (TeBrake, 2002). Thus, we believe that populated floodplains offer a great opportunity to detect and understand socio-hydrological processes.

A number of social studies have shown how the severity and frequency of floods can determine whether human settlements in floodplains are viable and sustainable (Myers et al., 2008; Green et al., 2011; Schultz and Elliott, 2012). Meanwhile, many hydrological studies have investigated the impact of human activities (Fig. 1) such as flood control, land-use changes and urbanisation on the frequency and severity of floods (Brath et al., 2006; Di Baldassarre et al., 2009; Heine and Pinter, 2012). Heine and Pinter (2012), for instance, analyzed the effect of levee building (one of the most common flood control measures) on flood levels. They proved by means of an empirical assessment, that, while there is no significant effect of the levee construction during the non-flood condition, the levee system does have in flood condition (i.e. the one for which this control measure is expected to work) "an abrupt, statistically significant and generally large in magnitude" (p. 3225) effect on the water levels at the study sites upstream or within reaches protected by levees. This confirms similar findings of Di Baldassarre et al. (2009) in their study to analyse the impact of human interventions through structural measures on the hydrological response. 

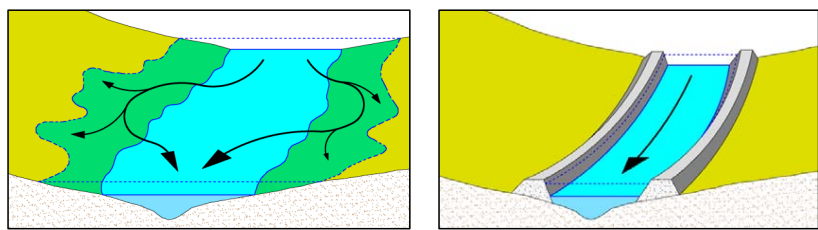

Fig. 1. Humans' alterations of physical processes in floodplains: schematic example of unprotected floodplains, which typically exhibits richness of natural processes and complex inundation patterns (left panel); schematic example of protected floodplain, whereby flood propagation processes are typically controlled by man-made structures, such as levees or dikes (right panel).

As an example of two-way interactions between human and water systems, Fig. 2 shows how societies mobilise capital, labour, political will and scientific expertise to rationalise, build, and raise levees to "protect" floodplains (red downward arrow). This then reduces the frequency of flooding in priority areas which are deemed (economically, politically, socially and culturally) important. Following this, as a result of the reduced frequency of flooding for some segments of society, these forms of development and settlement continue to take place, and expand, in the floodplain (Fig. 2, bottom panel). Based on this pattern, White (1945) identified a "levee effect", whereby, paradoxically, flood control structures might even increase flood risk, as protection from frequent flooding reduces perceptions of risk and encourages (certain kinds of) human settlements in floodplain areas, which are then vulnerable to high-consequence and low-probability events (Burton and Cutter, 2008; Di Baldassarre et al., 2009; Ludy and Kondolf, 2012). Thus, the process of building and raising levees often leads to a shift from frequent flooding of rural areas to rare, but potentially catastrophic, flooding of urbanised or industrialised areas. In response to these unintended consequences of levee building, some societies have then changed and adapted their approach to floodplain management. For example, in some regions, such as in the Netherlands and California, there has been a shift from continuous levee heightening to give back some room to the river (Fig. 2, green arrow) via floodplain reconnection (Opperman et al., 2009). This shift in human adjustment to floods involves not only a change in engineering approach, but also social, political, and cultural processes (Disco, 2002; Bijker, 2007).

Social scientists have also studied the political choices implicit in patterns of risk distribution, as protection for particular places implies trade-offs for other places. In the colonial city of Batavia (currently Jakarta, Indonesia), a ten-meterwide flood canal (Banjir canal) was constructed to protect the European colonial population from flood risk in the capital city (van Breen, 1917). However, directing of flood waters away from the economic interests, commercial activities and settlements of colonial authorities left informal indigenous settlements at greater risk and physically discouraged

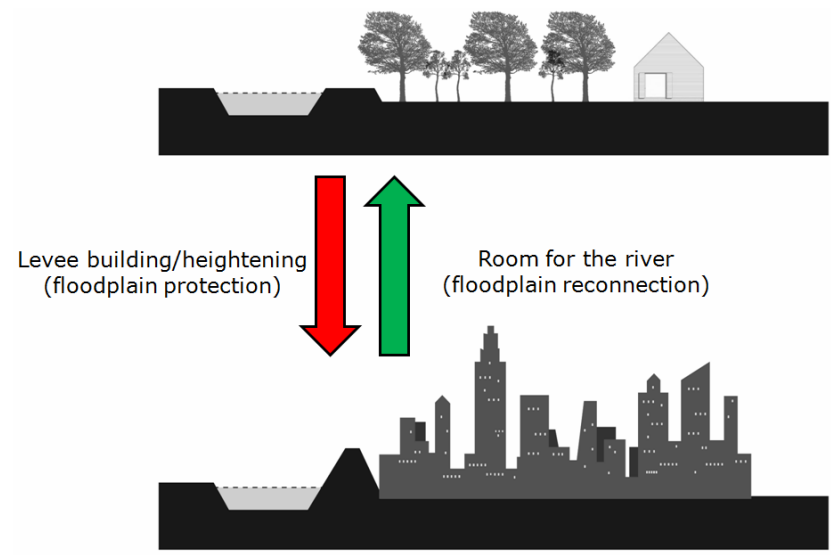

Fig. 2. Floodplains as fully coupled human-water systems: shifts in floodplain management between "living with floods" (top panel) and "fighting floods" (bottom panel).

their investment in housing and commercial activities. In response, low-income informal settlements emerged along the banks of the canal as this no-build, yet high-risk, space became physically available for habitation, provided proximity to a water supply, and ensured the absence of higher income land uses in what was considered marginal space (Abeysekere, 1989). In current-day Jakarta, the continued informal urban poor settlements along this bank has severely compromised its flood water protection capacity as the canal volume is increased by wastewater discharge from households, while flow is impeded by dumping of solid waste. This raises the risk of flooding not only for informal settlements directly adjacent to the canal, but for the entire city (Caljouw et al., 2005; World Bank, 2011).

These examples are meant to illustrate various relationships and consequences that take place in floodplains. First, the responses of societies to flood risk and flood events can change the probability of flooding as well as the interrelated adverse potential consequences (White's levee effect). Second, the mobilisation towards, processes of, differential effects of flood risk protection and engagement with flood events unfold within social relations. Flood protection is enrolled within social, as well as hydrological, relations of power as certain kinds of settlements, economic activities, and social organisation are made more or less possible. Adaptations in responses to floodplain dynamics are therefore simultaneously social (and by this we mean also political, economic, and cultural), technical, and ecological processes. Thus, if social-nature relations have an impact on how flood risk protection unfolds in the present (defining interventions and determining where, who and what will be protected and to what level), then past and future changes to flood dynamics also need to be understood as the product of historically produced political, economic, social and hydrological relations of power. 


\section{Current limitations in understanding floodplains}

The dynamic interactions between the hydrological and social dimensions of floods and the ways in which they co-produce subsequent hydrological and social processes through feedback mechanisms are poorly understood. As a result, theoretical insights are currently limited in their ability to explain these complex floodplain dynamics.

In hydrology, humans are currently considered as an external forcing (or boundary condition) to the floodplain system without representing these relevant reciprocal effects of social relations on hydrological processes. Hence, predictions of future trajectories of floodplain dynamics over long time scales (30-50 yr) are unavoidably incomplete and in many cases misleading. For instance, by referring to the example of Fig. 2, when flood prevention measures are planned and designed, state-of-the-art models can indeed provide quantitative predictions of the corresponding reduction of flooding probability. However, there are no insights about how such a reduction, within particular types of social organisation and socio-political relations, might then encourage (formal or informal) human settlements and therefore trigger an increase of the potential adverse consequences of flooding. Neither can we figure out how the latter will in turn lead to the requirement of additional flood prevention measures, as the ways in which such settlements impact upon hydrological processes is informed by social relations: the inclusion of informal settlements into planning processes, provision of urban services such as waste removal, monitoring of zoning regulations in no-build areas, political processes, intra-city migration patterns of such populations, and perceptions of risk across various social-economic classes in society. Our current inability to understand socio-hydrological processes that are taking place in floodplains as human-water systems is of serious concern, as this lack often contributes to further increased flood risk by limiting our ability to use appropriate land-use and urban planning, and understand potential implications of structural interventions given different social settings.

The scientific literature has traditionally addressed the analysis of flood risk by means of mono-disciplinary (or also multidisciplinary, within the same realm of science) approaches, whereby water and human systems are typically treated separately by using two (or more) different methods, based on hydrological and socio-economic methods. Natural scientists focus on the study of the probability of flooding (i.e. hazard), while social scientists examine the exposure, vulnerability or resilience of the system (Apel et al., 2009; Di Baldassarre et al., 2010; Harvey et al., 2012; Pappenberger et al., 2012; Winsemius et al., 2013; www.kulturisk.eu). However, the aforementioned examples showed that, in reality, the two components are deeply intertwined. Any changes in flood hazard lead to changes in vulnerability (levee effect), and vice versa (Fig. 2). Hence, while much progress has been made in the static assessment of (current) flood risk, addi- tional transdisciplinary research is required for the development of methods for the dynamic assessment of (future) flood risk, which is very much needed in a rapidly changing environment.

Recently, some interesting attempts in integrating human and water systems in flood analysis have been proposed (Dutta et al., 2003; Werner and MacManara, 2007). However, given the aforementioned lack of understanding of the interactions and feedback loops between social and hydrological processes, the coupling was often done with reference to specific case studies. For instance, Werner and MacManara (2007) simulated the development of New Orleans via complex landscape, damage, and socio-economic (agentbased) modelling, whereby these different components were linked with assumptions based on site-specific observations.

Thus, although these recent research works did represent a fundamental step into moving from mono-disciplinary to interdisciplinary approaches, they did not advance our understanding of the interactions and feedback loops between human and water systems, required for the dynamic assessment of (future) flood risk.

\section{Towards a transdisciplinary understanding of floodplains}

To address the inter-related, complex, and dynamic sociohydrological challenges in floodplains, we propose a transdisciplinary approach. This will enable an understanding of how social relations influence flood hydrology, while the hydrology of floods influences the unfolding of social relations.

For this purpose, we suggest historical, empirical, transdisciplinary studies of structural interventions within several floodplains characterised by diverse hydrological conditions and socio-political contexts. Investigating differences in the structural interventions and the dominant flood mitigation approaches sets a rich research agenda: how these different socio-technical approaches in floodplains are formed, adapted and reformed through social, political, technical and economic processes; how they require and/or entail a reordering of social relations leading to shifts in governance and creating new institutions, organisations and knowledge; and how these societal shifts then impact floodplain hydrology. It is expected that the interpretation of the reciprocal effects and interactions between floods and societies taking place in diverse floodplains will ultimately facilitate the development of theories explaining the dynamics of floodplains as coupled human-water systems. In this context, conceptualising human-flood interactions can be a fruitful way to formalise knowledge from different disciplines, formulate hypotheses, and explore long-term dynamics (Di Baldassarre et al., 2013).

Understanding the way societies approach, understand, control and influence flood conditions - and why - while they are also shaped by them is a challenging research agenda. 


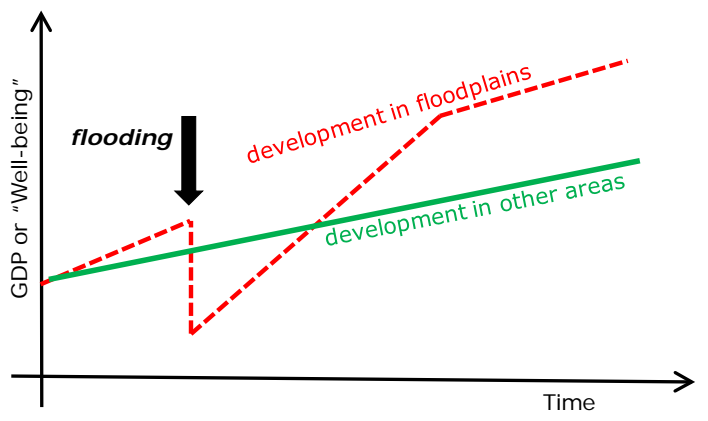

Fig. 3. Hypothesis of future trajectories of floodplain dynamics: flood disasters as shocks to the system (after Green et al., 2011), whereby the frequency and severity of floods will eventually determine if development in the floodplain (red dotted line) is more or less desirable than development in other areas (green line).

Some principles, such as entropy or optimality (Parker and Smith, 1990), might serve to this purpose. For instance, it can be hypothesised that societies react and adjust to a changing environment pursuing the maximisation of their benefits or minimising the (perceived) costs (Fig. 3). However, defining cost and benefit functions of people is difficult as human decision-making is often a balance of multiple, conflicting objectives, and the attitude towards risk and uncertainty can strongly vary across human societies depending on political and socio-economic conditions as well as cultural values (Eiser et al., 2012; Wachinger et al., 2012). Moreover, humans have powerful tools to shape floodplain dynamics that go beyond the adaptation strategies of natural ecosystems, and the development of these tools themselves can be boosted by (often unpredictable) technological revolutions (Taleb, 2007). As a result, the trajectories of societies can exhibit abrupt jumps that are much more dramatic that than the ones we typically see in "nature". For these reasons, the complex dynamics of floodplains as deeply intertwined humanwater systems might eventually be unpredictable in quantitative terms. However, although floodplain theories might exhibit limited predictive power, they have an important value by explaining the complex interactions and reciprocal links between floods and societies. This in turn can be used to define the range of variables which do need to be considered in any prediction, so as to prevent maladaptive responses or even false knowledge.

The understanding of the socio-hydrology of floodplains will therefore ultimately help to overcome the current lack of fundamental science underpinning integrated flood risk management. New knowledge about the evolution of floodplains as human-water systems will also improve floodplain modelling by including social processes and human activities as intrinsic dynamics of floodplains rather than a boundary condition - and therefore contribute to planning better measure to reduce flood risk. Moreover, the development of sociohydrological theories will provide additional benefits, such

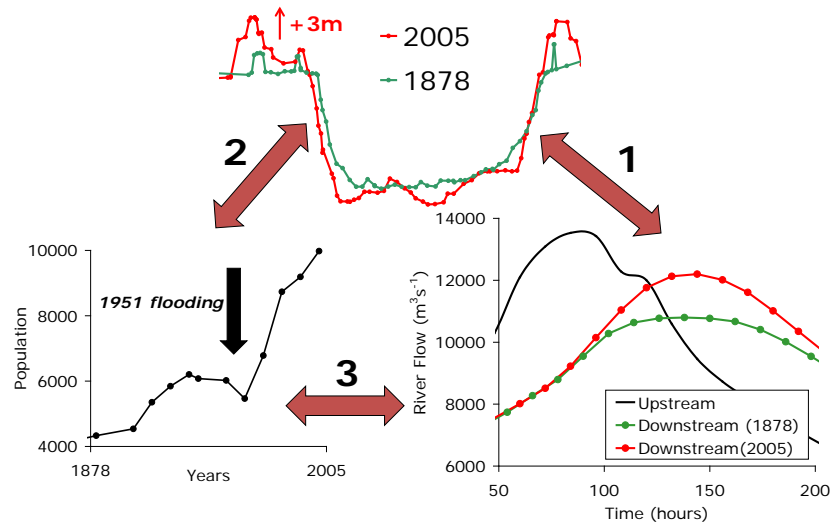

Fig. 4. Analysing the socio-hydrology of floodplain systems: changes in the cross section of Po River at Pontelagoscuro (Italy) in the period 1878-2005, showing the significant levee heightening of around $3 \mathrm{~m}$ (top panel); hydrological changes in flood magnitude due to levee heightening (bottom right); human population dynamics in the floodplain areas "protected" by the (continuously heightened) levees (bottom left panel).

as emphasising the role of social relations in floodplain science and providing a concrete example of the advantage of bringing together physical and social science disciplines for what will be increasingly needed in the future: transdisciplinary approaches to understanding hydrological change.

\section{Methodological implications of transdisciplinary research}

As discussed in the previous sections, conventional hydrological science studies, endeavours in understanding floodplain dynamics, consider human activities as external forcing and often aim to predict future dynamics. Their main aim is to discover universally applicable (natural) laws that can help in solving problems such as preventing flood events. Traditionally, critical social scientists focus on studying the past to understand the present, and the predictive capacity within the social sciences realm remains limited. Even though progress has been made in social-nature studies by internalising hydrological processes and material properties in understanding how social relations unfold and how societies become organised, this mainly builds on highly context-specific insights and thus far we have not discovered in literature such studies carried out in floodplains. Engaging in transdisciplinary research therefore has considerable methodological implications to transcend these differences while building on the conceptual strengths of each.

Initial interesting insights might be derived by analysing long time series of hydrological data and human population dynamics in specific case studies. For instance, Fig. 4 shows a qualitative data analysis of floodplain dynamics for the Po River in Italy, which provides an example of a first step into 
transdisciplinary research activities that can be performed to increase our understanding of socio-hydrological processes in floodplains. The top panel of Fig. 4 shows how the river cross section has changed in the period 1878-2005 and, in particular, the fact that levees were heightened about three meters. Arrow 1 of Fig. 4 summarises the results of a recent study, which demonstrated that this levee heightening led to an increase of the magnitude of floods because of reduced storage of flood water (Di Baldassarre et al., 2009). The Arrow 2 of Fig. 4 shows that building and raising levees have also contributed to changes in perception of flood risk, illustrated by the increase of human population in floodplain areas (the aforementioned "levee effect", see Fig. 2). The population growth was first interrupted by the occurrence of the Word War II and then, much more dramatically, by the occurrence of the large flood disaster of 1951 (Fig. 4). Interestingly, the severity of the 1951 flooding was in turn exacerbated by the aforementioned increase of flood magnitude due to levee heightening (Arrow 3 of Fig. 4). Afterwards, levees and dikes were reinforced and further heightened and this led to a renovated increase of human population in the "protected" floodplain areas (Fig. 4). However, it should be mentioned that the changes in flood frequency might be driven by other causes, such as climate change and variability (Merz et al., 2012), while the settlement patterns might be influenced by other socio-political and economic processes. Caution is thus required in detecting and attributing trends which might lead to difficulties in drawing substantial conclusions on these kinds of studies alone.

Hence, a second step is needed to compliment the research with additional studies to cross-check the findings as well as to better understand the social relations and organisation productive of the observed interactions. For instance, in-depth analysis could provide insight into the decision making process around the heightening of the levee and how particular modes of governance, dominant in society, led to this particular technical intervention over other options. Moreover, in-depth analysis is needed to understand how risks are perceived and distributed among various socio-economic classes and other social constructs (e.g. gender, ethnicity) and how this influenced human settlement patterns. This in turn will contribute to understanding how differential outcomes are produced in the engagement with nature and how this potentially leads to structural inequities in society that influence (future) decision-making processes. For these analyses, ethnographic empirical research is needed based on quantitative (e.g. surveys) and qualitative (e.g. interviews, observations) research methodologies in combination with deskstudies of policy, legal and financial documents.

Once rich understandings are obtained for particular floodplains, step three in the proposed research approach then involves comparative analysis of floodplain systems across different social-political contexts, various ecological conditions influenced by levels of human impact (from pristine to strongly urbanised areas), and diverse hydro-climatic con- ditions (from dry to humid and tropical regions). A great opportunity to examine floodplains as human-water systems is offered nowadays by the current "flood of data", i.e. the proliferation of global space-borne data (Lincoln, 2007), to perform a worldwide comparative analysis (Bloeschl, 2006) of floodplains as human-water systems. In particular, various sources of remote sensing data characterised by a spatial resolution useful for the observation of the most significant floodplain dynamics (50-250 m; Blyth, 1997; Apel et al., 2009: Di Baldassarre et al., 2011) are currently available, such as: space-borne digital elevation models for the numerical description of floodplain topographies (LeFavour and Alsdorf, 2005; Schumann et al., 2010); flood extent maps derived from satellite imagery for the observation of inundation patterns (Alsdorf and Lettenmaier, 2003; Di Baldassarre et al., 2011); and population distribution data for tracking patterns of human settlements (Linard and Tatem, 2011; Linard et al., 2012).

Additional sources of valuable data for the observation of floodplain dynamics are the global river flow archives (e.g. WMO Global Runoff Data Centre; UNESCO FRIEND European Water Archive; Hannah et al., 2011) and databases of recorded flood disasters (e.g. Dartmouth Flood Observatory) along with information about the human interactions with the environment (e.g. land-use maps, flood control infrastructures). Lastly, it is worth mentioning that more floodplain data are expected in the near future, such as the ones from the SWOT mission (Surface Water and Ocean Topography; Alsdorf et al., 2007), which will measure water levels to centimetric accuracy every ten days with complete global coverage for all rivers above hundred meter wide.

These new sources of social and hydrological data can be used to identify significant relationships between the occurrence of flooding and patterns of human settlements. This can be done by performing a spatial regression analysis for numerous diverse floodplain systems in terms of hydrological condition and socio-political context. Emerging patterns and interrelations then need to be cross-checked with the indepth empirical research obtained within specific floodplains and, where needed, complemented with additional empirical research in other floodplains and/or socio-political historic studies at larger spatial scales to test hypotheses and further enrich our understanding of floodplain systems.

Hence, instead of using these new data sources to calibrate "old models", as the current approach would suggest, there is a need to iteratively exploit the new observations to track floodplain dynamics, look for emerging behaviours, complement this with context-specific empirical research. This will allow scientists and practitioners to work together to test hypotheses about ways in which social and hydrological processes interact within floodplain systems to change flood risk, and distribution of risk across society. 
Acknowledgements. The authors would like to thank Jaap Evers for providing comments on an earlier draft of this paper, while Domenico Di Baldassarre is acknowledged for sketching figures. Part of the research work of Giuliano Di Baldassarre was funded by the European FP7 Project KULTURisk (Grant Agreement no. 265280).

Edited by: T. J. Troy

\section{References}

Abeyasekere, S.: Jakarta: A History, Oxford University Press, Singapore, 1989.

Apel, H., Aronica, G. T., Kreibich, H., and Thieken, A. H.: Flood risk analyses - how detailed do we need to be?, Nat. Hazards, 49, 79-98, 2009.

Alsdorf, D. E. and Lettenmaier, D. P.: Tracking Fresh Water from Space, Science, 301, 1491-1494, 2003.

Alsdorf, D. E., Rodriguez, E., and Lettenmaier, D. P.: Measuring surface water from space, Rev. Geophys., 45, RG2002, doi:10.1029/2006RG000197, 2007.

Armitage, D., Berkes, F., and Doubleday, N.: Adaptive CoManagement. Collaboration, Learning, and Multi-Level Governance, Vancouver: UBC Press, 15 pp., 2007.

Bakker, K.: Water: Political, biopolitical, material, Soc. Stud. Sci., 42, 616-623, 2012.

Barnes, J.: Pumping possibility: Agricultural expansion through desert reclamation in Egypt, Soc. Stud. Sci., 42, 517-538, 2012.

Barnes, J. and Alatout, S.: Water worlds: Introduction to the special issue of Social Studies of Science, Soc. Stud. Sci., 42, 483-488, 2012.

Bates, P. D.: Integrating remote sensing data with flood inundation models: how far have we got?, Hydrol. Proc., 26, 2515-2521, 2012.

Bates, P. D. and De Roo, A. P. J.: A simple raster-based model for floodplain inundation, J. Hydrol., 236, 54-77, 2000.

Berkes, F. and Folke, C.: Linking social and ecological systems. Management practices and social mechanisms for building resilience. Cambridge, UK: Cambridge University Press, 476 pp., 1998.

Bijker W.: Dikes and dams, thick with politics, Isis, 98, 109-123, 2007.

Blyth, K.: FLOODNET: a telenetwork for acquisition, processing, and dissemination of Earth Observation data for monitoring and emergency management of floods, Hydrol. Proc., 11, 1359-1375, 1997.

Bloeschl, G.: Hydrologic synthesis-across processes, places and scales. Special section on the vision of the CUAHSI National Center for Hydrologic Synthesis (NCHS), Water Resour. Res., 42, W03S02, doi:10.1029/2005WR004319, 2006.

Brath, A., Montanari, A., and Moretti, G.: Assessing the effect on flood frequency of land use change via hydrological simulation (with uncertainty), J. Hydrol., 324, 141-153, 2006.

Braun, B.: Producing vertical territory: geology and governmentality in late-Victorian Canada”, Ecumene, 7, 7-46, 2000.

Budds, J.: Contested H2O: Science, policy and politics in water resources management in Chile, Geoforum, 40, 418-430, 2009.

Burton, C. and Cutter, S. L.: Levee failures and social vulnerability in the Sacramento-San Joaquin Delta area, California, Nat.
Hazards Review, 9, 136-149, 2008.

Caljouw, M., Nas, P., and Pratiwo L.: Flooding in Jakarta: Towards a blue city with improved water management. Bijdragen tot de taal-, land- en volkenkunde, J. Human. Soc. Sci. Southeast Asia, 61, 454-484, 2005.

Carroll, P.: Water and technoscientific state formation in California, Soc. Stud. Sci., 42, 489-516, 2012.

Carse, A.: Nature as infrastructure: Making and managing the Panama Canal watershed. Soc. Studi. Sci., 42, 539-563, 2012.

Castree, N. and Braun, B.: Social nature: theory, practice, politics, Oxford: Blackwell Publishers, 248 pp., 2001.

Cioc, M.: The Rhine: An Eco-Biography, Seattle: University of Washington Press, 272 pp., 2002.

Di Baldassarre, G. and Montanari, A.: Uncertainty in river discharge observations: a quantitative analysis, Hydrol. Earth Syst. Sci., 13, 913-921, doi:10.5194/hess-13-913-2009, 2009.

Di Baldassarre, G. and Uhlenbrook, S.: Is the current flood of data enough? A treatise on research needs to improve flood modelling, Hydrol. Proc., 153-158, 2012.

Di Baldassarre, G., Castellarin, A., and Brath, A.: Analysis on the effects of levee heightening on flood propagation: some thoughts on the River Po, Hydrol. Sci. J., 54, 1007-1017, 2009.

Di Baldassarre, G., Montanari, A., Lins, H., Koutsoyiannis, D., Brandimarte, L., and Bloeschl, G.: Flood fatalities in Africa: from diagnosis to mitigation, Geophys. Res. Lett., 37, L22402, doi:10.1029/2010GL045467, 2010.

Di Baldassarre, G., Schumann, G., Brandimarte, L., and Bates, P. D.: Timely low resolution SAR imagery to support floodplain modelling: a case study review, Surv. Geophys., 32, 255-269, 2011.

Di Baldassarre, G., Viglione, A., Carr, G., Kuil, L., Salinas, J. L., and Blöschl, G.: Socio-hydrology: conceptualising human-flood interactions, Hydrol. Earth Syst. Sci. Discuss., 10, 4515-4536, doi:10.5194/hessd-10-4515-2013, 2013.

Disco, C.: Remaking "Nature": The Ecological Turn in Dutch Water Management, Sci. Technol. Human Val., 27, 206-235, 2002.

Dutta, D., Herath S., and Musiake K.: A mathematical model for flood loss estimation, J. Hydrol., 277, 24-49, 2003.

Eiser, J.R., Bostrom, A., Burton, I., Johnston, D., McClure, J., Paton, D., van der Pligt, J., and White, M.: Risk interpretation and action: A conceptual framework for research in the context of natural hazards, Int. J. Disaster Risk Reduct., doi:10.1016/j.ijdrr.2012.05.002, 2012.

Gandy, M.: Concrete and Clay: Reworking Nature in New York City. Cambridge, MA, MIT Press, 344 pp., 2002.

Green, C., Viavattene, C., and Thompson, P.: Guidance for assessing flood losses. CONHAZ Report, Flood Hazard Research Centre, Middlesex University, 2011.

Gunderson, L. H. and Holling, C. S.: Panarchy: understanding transformations in human and natural systems. Washington DC, USA, Island Press, 2002.

Gunderson, L. H., Holling, C. S., and Light, S. S.: Barriers and bridges to the renewal of ecosystems and institutions, Columbia University Press, 1995.

Hamlin, C.: A Science of Impurity: Water Analysis in Nineteenth Century Britain. Bristol, UK and Berkeley, CA, Adam Hilger and University of California Press, 332 pp., 1990.

Hannah, D. M., Demuth, S., van Lanen, H. A. J., Looser, U., Prudhomme, C., Rees, G., Stahl, K., and Tallaksen, L. M.: Large-scale 
river flow archives: importance, current status and future needs, Hydrol. Proc., 25, 1191-1200, 2011.

Harvey, H., Hall, J. W., and Peppé, R.: Computational decision analysis for flood risk management in an uncertain future, J. Hydroinform., 14, 537-561, 2012.

Heine, R. A. and Pinter N.: Levee effects upon flood levels: an empirical assessment, Hydrol. Proc., 26, 3225-3240, 2012.

Horritt, M. S. and Bates, P. D.: Evaluation of 1D and 2D numerical models for predicting river flood inundation, J. Hydrol., 268, 8799, 2002.

Horritt, M.S., Di Baldassarre, G., Bates, P. D., and Brath, A.: Comparing the performance of 2-D finite element and finite volume models of floodplain inundation using airborne SAR imagery, Hydrol. Proc., 21, 2745-2759, 2007.

Hunter, N. M., Bates, P. D., Horritt, M. S., and Wilson, M. D: Simple spatially-distributed models for predicting flood inundation: A review, Geomorphology, 90, 208-225, 2007.

Jahn, T., Bergmann, M., and Keil, F.: Transdisciplinarity: Between mainstreaming and marginalization, Ecol. Econom., 79, 1-10, 2012.

Kareiva, P., Watts, S., McDonald, R., and Boucher, T.: Domesticated Nature; Shaping Landscapes and Ecosystems for Human Welfare, Science, 316, 5833, 1866-1869, 2007.

Landstrom, C., Whatmore, S. J., Lane, S. N., Odoni, N. A., Ward, N., and Bradley, S.: Coproducing flood risk knowledge: redistributing expertise in critical participatory modelling, Environ. Plann., 43, 1617-1633, 2011.

Lane, S. N., Odoni, N., Landstrom, C., Whatmore, S. J., Ward, N., and Bradley, S.: Doing flood risk science differently: an experiment in radical scientific method, Trans. Inst. Brit. Geogr., 36, 15-26, 2011.

Latour, B.: We Have Never Been Modern, Cambridge, Harvard University Press, 1993.

LeFavour, G. and Alsdorf, D.: Water slope and discharge in the Amazon river estimated using the shuttle radar topography mission digital elevation model, Geophys. Res. Lett., 32, L17404, doi:10.1029/2005GL023836, 2005.

Linard, C. and Tatem, A. J.: Population mapping of poor countries, Nature, 474, p. 36, 2011.

Linard, C., Gilbert M., Snow, R. W., Noor, A. M., and Tatem, A.J. Population Distribution, Settlement Patterns and Accessibility across Africa in 2010, PLoS ONE, 7, e31743, 2012.

Lincoln, T.: Hydrology: Flood of data. Nature, 447, p. 393, 2007.

Linton, J.: What is Water? The History of a Modern Abstraction, UBC Press, Vancouver, 2010.

Liu, J., Dietz, T., Carpenter, S. R., Alberti, M., Folke, C., Moran, E., Pell, A. N., Deadman, P., Kratz, T., Lubchenco, J., Ostrom, E., Ouyang, Z., Provencher, W., Redman, C. L., Schneider, S. H., and Taylor, W. W.: Complexity of Coupled Human and Natural Systems, Science, 317, 1513-1516, 2007.

Luckin, B.: Pollution and Control: A Social History of the River Thames in the Nineteenth Century, Boston: Hilger, 1987.

Ludy, J., and Kondolf, G. M.: Flood risk perception in lands "protected" by 100-year levees, Nat. Hazards, 61, 829-842, 2012.

Masozera, M., Bailey, M., and Kerchner, C.: Distribution of impacts of natural disasters across income groups: A case study of New Orleans, Ecol. Econ., 63, 299-306, 2007.

Mcgranahan, G., Balk, D., and Anderson, B.: The rising tide: assessing the risks of climate change and human settlements in low elevation coastal zones, Environ. Urban., 19, 17-37, doi:10.1177/0956247807076960, 2007.

Merz, B., Vorogushyn, S., Uhlemann, S., Delgado, J., and Hundecha, Y.: HESS Opinions "More efforts and scientific rigour are needed to attribute trends in flood time series", Hydrol Earth Syst. Sci., 16, 1379-1387, doi:10.5194/hess-16-13792012, 2012.

Milly, P. C. D., Wetherald, R. T., Dunne, K. A., and Delworth, T. L.: Increasing risk of great floods in a changing climate, Nature, 415, 514-517, 2002.

Myers, C. A., Slack, T., and Singelmann, J.: Social vulnerability and migration in the wake of disaster: the case of Hurricanes Katrina and Rita, Pop. Environ., 29, 271-291, 2008.

Montanari, A., Young, G., Savenije, H. H. G., Hughes, D., Wagener, T., Ren, L. L., Koutsoyiannis, D., Cudennec, C., Toth, E., Grimaldi, S., Blöschl, G., Sivapalan, M., Beven, K., Gupta, H., Hipsey, M., Schaefli, B., Arheimer, B., Boegh, E., Schymanski, S. J., Di Baldassarre, G., Yu, B., Hubert, P., Huang, Y., Schumann, A., Post, D. A., Srinivasan, V., Harman, C., Thompson, S., Rogger, M., Viglione, A., McMillan, H., Characklis, G., Pang, Z., and Belyaev, V.: Panta Rhei - Everything Flows: Change in hydrology and society - The IAHS Scientific Decade, 2013-2022, Hydrol. Sci. J., 58, doi:10.1080/02626667.2013.809088, 2013.

Mosse, D.: The Rule of Water: Statecraft, Ecology, and Collective Action in South India. Oxford and New York: Oxford University Press, 352 pp., 2003.

Nardi, F., Vivoni, E. R., and Grimaldi, S.: Investigating a floodplain scaling relation using a hydrogeomorphic delineation method, Water Resour. Res., 42, W09409, doi:10.1029/2005WR004155, 2006.

Ohl, C. and Tapsell, S.: Flooding and human health: the dangers posed are not always obvious, Brit. Med. J., 321, 1167-1168, 2000.

Opperman, J. J., Galloway G. E., Fargione J., Mount J. F., Richter B. D., and Secchi S.: Sustainable floodplains through large-scale reconnection to rivers, Science, 326, 1487-1488, 2009.

Ostrom, E.: A general framework for analysing sustainability of social-ecological systems. Science, 325, 419-422, 2009.

Pappenberger, F., Dutra, E., Wetterhall, F., and Cloke, H. L.: Deriving global flood hazard maps of fluvial floods through a physical model cascade, Hydrol. Earth Syst. Sci., 16, 4143-4156, doi:10.5194/hess-16-4143-2012, 2012.

Parker, G. A. and Smith J. M.: Optimality theory in evolutionary biology, Nature, 348, 27-33, 1990.

Pritchard, S.: Confluence: The Nature of Technology and the Remaking of the Rhone, Cambridge, MA, Harvard University Press, 2011.

Rademacher, A.: Reigning the River: Urban Ecologies and Political Transformation in Kathmandu, Durham, Duke University Press, 2011.

Sanderson, E. W., Jaiteh, M., Levy, M. A., Redford, K. H., Wannebo, A. V., and Woolmer, G.: The human footprint and the last of the wild, BioScience, 52, 891-904, 2002.

Savenije, H. H. G., Hoekstra, A. Y., and van der Zaag, P.: Evolving water science in the Anthropocene, Hydrol. Earth Syst. Sci. Discuss., 10, 7619-7649, doi:10.5194/hessd-10-7619-2013, 2013.

Schumann, G., Di Baldassarre, G., Alsdorf, D. E., and Bates, P. D.: Near real-time flood wave approximation on large rivers from space: application to the River Po, Northern Italy, Water Resour. 
Res., 46, W05601, doi:10.1029/2008WR007672, 2010.

Scheffer, M., Carpenter, S. R., Foley, J. A., Folke, C., and Walker, B.: Catastrophic shifts in ecosystems, Nature, 413, 591-596, 2001.

Schultz, J. and Elliott, J. R.: Natural disasters and local demographic change in the United States, Pop. Environ., 34, 293-312, 2012.

Sivapalan, M., Savenjie, H. G., and Blöschl, G.: Socio-hydrology: A new science of people and water, Hydrol. Proc., 26, 1270-1276, 2012.

Swyngedouw, E.: Modernity and hybridity: Nature, regeneracionismo, and the production of the Spanish waterscape, 18901930, Ann. Assoc. Am. Geogr. 89, 443-465, 1999.

Taleb, N. N.: The Black Swan: The Impact of the Highly Improbable. New York: Random House and Penguin, ISBN 978-1-40006351-2, 2007.

Tarr, J.: The Search for the Ultimate Sink: Urban Pollution in Historical Perspective. Akron, OH: University of Akron Press, 1996.

United Nations Department of Economic and Social Affairs/Population Division World Urbanization Prospects: The 2011 Revision, New York, 2012.

van Breen, H.: Kleine werken ter verbetering van den gezondheidstoestand der hoofdplaats Batavia, De Waterstaats Ingenieur, 3, 130-138, 1917.

Wachinger, G., Renn, O., Begg, C., and Kuhlicke, C.: The Risk Perception Paradox-Implications for Governance and Communication of Natural Hazards, Risk Anal., 33, 1049-1065, doi:10.1111/j.1539-6924.2012.01942.x, 2012.
Wagener, T., Sivapalan, M., Troch, P. A., McGlynn, B. L., Harman, C. J., Gupta, H. V., Kumar, P., Rao, P. S. C., Basu, N. B., and Wilson, J. S.: The future of hydrology: An evolving science for a changing world, Water Resources Research, 46, W05301, doi:10.1029/2009WR008906, 2010.

Werner, B. T. and McNamara, D. E.: Dynamics of coupled humanlandscape systems, Geomorphology, 91, 393-407, 2007.

White, G. F.: Human Adjustments to Floods. Department of Geography Research, Paper no. 29, The University of Chicago, Chicago, 1945.

White, R.: The Organic Machine: The Remaking of the Colorado River, New York: Hill and Wang, 1996.

Winsemius, H. C., Van Beek, L. P. H., Jongman, B., Ward, P. J., and Bouwman, A.: A framework for global river flood risk assessments, Hydrol. Earth Syst. Sci., 17, 1871-1892, doi:10.5194/hess-17-1871-2013, 2013.

World Bank: Indonesia - Jakarta Urgent Flood Mitigation Project (Jakarta Emergency Dredging Initiative) Project Appraisal Document, Report No: 65973-ID, World Bank: Jakarta, 2011.

Worster, D.: Rivers of Empire: Water, Aridity, and the Growth of the American West. New York: Oxford University Press, 1992. 